\title{
The World Alpine Ski Championships 1989, 1999 and 2015 in Vail, Colorado: Impacts, Issues and the Quest for Sustainable Resort Development
}

\author{
Rudi Hartmann \\ University of Colorado Denver, Department of Geography and Environmental Sciences
}

\begin{abstract}
Mega sports events like the 1989, 1999 and 2015 World Alpine Ski Championships in Vail \& Beaver Creek and the changing practice and promotion of skiing in general initiated waves of modernization for mountain operations and the tourism infrastructure. Vail's transformation from a small attractive ski area with an alpine inspired village to an upscale four season resort environment stretching over fifty miles $(70 \mathrm{~km})$ will be reconstructed.

Vail Valley, with two large ski areas, Vail and Beaver Creek, has become one of the most highly recognized tourist destination areas in the State of Colorado. The beginnings of the Vail Ski Area 1958 - 1963 were plagued by legal and logistical problems. In the mid/late 1960s and 1970s the uses of the ski area took off rapidly with the result of Vail becoming the leading ski area nationwide. Rapid resort development on the valley floor resulted in debates and conflicts over the expansion of Vail Associates/Vail Resorts' skiable terrain on the mountain including the Colorado voters' rejection of the 1976 Winter Olympics and the 1998 Earth Liberation Front's arson attack on Vail Mountain.

At last, Vail Resorts, the operator of the Vail and Beaver Creek ski areas, has embraced sustainability as a goal, and the resort company has taken steps (with 'green' policies and programs) toward a sustainable future for the Valley. In the final section, equity issues in the uses of the resort areas and the nearby public lands are discussed.
\end{abstract}

Keywords: Vail Valley, Vail Ski Area, World Alpine Ski Championships, Mega Events, Development, Sustainability

\section{INTRODUCTION}

The Gore and northern Swatch Mountains of Colorado were subject to two divergent land use initiatives 1960-1980: the development of two ski areas, Vail and Beaver Creek, on national forest land and the designation of two wilderness areas, the Eagles Nest and Holy Cross Wilderness Areas. Subsequently, an extended narrow urbanized corridor along Gore Creek and the Eagle River evolved, commonly known as Vail Valley. Improvements in the transportation infrastructure made this once sparsely traveled mountain area more and more accessible from Denver and the Front Range, first with the extension of U.S. Highway 6 over 'Vail Pass' (in the honor of long-time highway engineer Charlie Vail) in the 1940/50s and eventually with the construction of an Interstate highway (I-70) through Vail Valley in the mid and late 1970s. Vail has become one of the leading ski areas in North America and a four season resort environment visited by millions of people each year. The built-up areas along the valley floor initially confined to the base(s) of the ski area have sprawled East and Westwards over fifty miles (seventy $\mathrm{km}$ ), with waves of modernization and restructuring affecting both the core resort areas as well as the 'down valley'. In short, after periods of neglect and oblivion this distinct part of the Colorado high country marks one of the most highly recognized tourist destination areas of the state.

The focus of this article is the impact of the skiing sport and mega winter sports events on mountain resort development in general, with an examination of the role of the 1989, 1999 and 2015 World Alpine Ski Championships in Vail and Beaver Creek in particular.

At last, Vail Resorts, the operator of the Vail and Beaver Creek ski areas, has embraced sustainability as a goal, and the resort company as well as the Town of Vail have taken steps (with 'green' policies and programs) toward a sustainable future for the Valley. In the final section of the article, questions about equity issues will be raised in regard to the accessibility and uses of the resort areas and the nearby federal lands. 


\section{Vail/Beaver Creek's Path to Premier Ski Areas in North America and to HOSTING THE WORLD ALPINE SKI CHAMPIONSHIPS}

The opening of the Vail ski area on December 15, 1962 was preceded by a series of problems. The White River National Forest Service had denied the first application for a special permit. Pete Seibert, a member of the 10th Mountain Division during WW II, and Earl Eaton, an Eagle County native and uranium prospector in the 1950s, recognized the potential of then unnamed Vail Mountain in a joint skiing trip in 1957 (Seibert 2000, Simonton 1987, p. 62). While Seibert, a successful ski racer, had considerable experience in ski area management from his work at Loveland Ski Area, Earl Eaton provided the detailed knowledge of the mountain terrain and of the local conditions. In order to create a new ski area on national forest lands Seibert and Eaton invited a group of investors which formed under the deceptive ploy of a rod and gun club along the upper Gore Creek area west of Vail Pass. The group, which bought up the land on the valley floor from several local ranchers including sheep herders, eventually incorporated as Vail Associates, Ltd. When the group applied for the special permit, they found themselves in a competitive situation with other new ski area ventures in the late 1950s, most of all with Aspen Highlands and Breckenridge which were given preference by the National Forest Service. After protests and political pressure on the White River National Forest Service, Vail's application was approved. Though, the permit carried strict conditions, with the imposition of substantial financial requirements before being allowed to start construction of the new ski area (Childers 2012, Hauserman 2000, Simonton 1987).

Besides legal and financial challenges, the construction of the Vail Ski Area was plagued by technological and logistical issues. The shipment of the necessary parts for building the uphill transportation system at Vail Mountain (consisting of a gondola and several double chair lifts) had to be rerouted during the spring/summer of 1962. While warm and dry conditions into October/November/December helped to complete the job by opening day, the skiing conditions were marginal because of the lack of snow. A snow storm over Christmas finally allowed opening the whole mountain for the interested skiing public. The second ski season also saw severe snow problems, particularly in December 1963 when Ute Indians were invited to perform a 'rain dance'. Overcoming the various difficulties and problems during the beginning stage of the ski area 1959 1963 became part of the 'Vail myth' fifty years later, as emphasized in the recollections of the 'finders' and 'founders' of Vail and in the narrative of the "Vail Dream Realized" exhibit shown at the Colorado Ski and Snowboard Museum during the anniversary events 2012 (Seibert 2000, Hauserman 2000, Colorado Ski \& Snowboard Museum 2012, Brown and Burns 2012, Childers 2012).

Vail Village, based on a plan modeled after alpine towns (Dorward 1990, pp. 208 - 211; Dorward 2006), was started in 1963/64/65. Though, resort development could not be limited to the planned area. It soon spread beyond the Village on the valley floor as the ski area expanded on the mountain, with Lionshead forming a second base of a considerably enlarged Vail ski area by 1968. It was not only the front of the mountain that attracted advanced skiers but also several back bowls with the potential for deep snow skiing in ungroomed terrain. These unique qualities of the Vail ski area were effectively promoted by a seasoned marketing team under the leadership of Bob Parker, like Pete Seibert a former member of the 10th Mountain Division and now editor of Skiing Magazine. Early on, they enticed national ski racing teams to practice on Vail Mountain. It has been argued that it was these skilled marketing efforts - in addition to a rapid pace in new construction drawing in many new residents to the 1966 incorporated Town of Vail - that propelled the Vail ski area past Aspen as the most popular ski area in Colorado by 1969/70 (Fay 1984; Colorado Ski History 2016; Hauserman 2000).

Beaver Creek became the second ski area developed and operated by Vail Associates. Located fourteen miles $(20 \mathrm{~km})$ west of Vail it had a luxuriously designed village base as well as access to four mountains, one of which had high qualities for downhill ski racing. World renowned downhill ski racers Bernard Russi and Cindy Nelson were eventually hired as consultants to help design the "Birds of Prey" downhill course which became one of the most challenging speed events within the FIS World Cup races.

Beaver Creek Ski Area bordering the Holy Cross Wilderness Area was opened with considerable delay, in 1980. Several reasons contributed to this including high development costs of the Village at Beaver Creek paired with Vail Associates' overall preference for improvements and further 
expansions at the more accessible Vail Ski Area. Further, initial plans and efforts to buy up the land from local ranchers did not materialize. It was not until 1972 that the negotiations for the purchase were successfully settled (Childers 2012; Hauserman 2000, Simonton 1987).

Most of all, it was the anti-growth movement in Colorado in the 1970s that put on hold the development of ski areas in Colorado in general and the Beaver Creek ski area (as the last new ski area along the I-70 corridor) in particular. Originally scheduled for hosting some of the alpine ski races for the 1976 Winter Olympics, Beaver Creek's development plans were suspended when the Colorado electorate voted in November 1972 against funding and hosting the 1976 Games. The environmental movement and its opposition to further ski area development on public lands will be dealt with in detail in a later section.

While rejection of the Winter Olympics was a temporary set-back, Vail was awarded the 1989 World Alpine Championships by the FIS (Federation Internationale de Ski) as Aspen declined to host them and Vail subsequently launched a successful bid. It would be the first of three championships held in Vail and Beaver Creek which will be the focus of the following chapters.

\section{What are Mega Sports Events in Alpine SKIING?}

There are three types of mega sports events in alpine skiing: Winter Olympic Games, World Alpine Ski Championships and FIS Alpine Ski World Cup races.

The first Winter Olympics in Chamonix, France 1924 did not include alpine skiing events. The politically troubled winter games of Garmisch-Partenkirchen, Germany in 1936 had the first combined skiing category. It was not until the Oslo Winter Olympics 1952 that the standard racing catalogue of downhill/giant slalom/slalom for men and women was established. The first Winter Olympics in the U.S. were held in Squaw Valley in 1960.

World Alpine Ski Championships have regularly been organized since the 1930s, eventually in two year intervals. The first event was hosted by the Town of Muerren, Switzerland in 1931. Virtually all the early world championships were held in ski towns of the Alps, with the exception of Zakopane, Poland in 1939. The first World Alpine Ski Championships held in the U.S. was in Aspen, Colorado 1950. Vail \& Beaver Creek would host the events three times (in 1989, 1999 and 2015), with only one other hosting community, St. Moritz, Switzerland, given the same honors (in 1974, 2003, and 2017) in the past fifty years.

FIS ("Federation Internationale de Ski") Alpine Ski World Cup races are an annual event following an international circuit of alpine skiing competitions. The first Cup was organized for the 1966/67 ski season. The circuit of races has grown from 20 to 30 events for men and women each in the 1970s to now 44 and 40 races respectively (2015/16 ski season). There is a predominance of race competitions held in Europe, particularly in the Alpine countries. In recent years, however, stops more frequently include North American ski resorts, with Aspen, Vail and Beaver Creek usually awarded to host the world cup races in Colorado. Since 1998, Beaver Creek has been the host of the 'Birds of Prey' World Cup events each year on the first weekend in December.

\section{What IS THE IMPACT OF MEga SPORTS EVENTS ON ECONOMIC DEVELOPMENT?}

For decades this question has been assessed by experts in the regional development field, notably by economists, public policy makers, applied researchers and consultants in business and marketing as well as by tourism researchers (see here, for instance, Ritchie 1984; Getz 1989, Hall 1989). The issue has left a long trail of studies first focusing largely on the dollar amount the communities have as an intake by hosting these mega sports events over a short time now shifting to the more complex questions of the long-term legacy and viability of the investments made for the sports venues and other infrastructure improvements.

The impact of, for instance, the 1988 Winter Olympics in Calgary, in Salt Lake City 2002, in Vancouver 2010 and in Sochi 2014 as well as of the Summer Olympics of London 2012 have been closely studied by local committees and interdisciplinary research groups (see, for instance, Ritchie and Aitken 1984; Center for Public Policy \& Administration The University of Utah 2006, Capital Projects Branch Province of British Columbia 2002, OGI-UBC Research Team The University of British Columbia 2013, Ritchie, Shipway \& Cleeve 2010, Mueller 2015). Methodologies of how to 
properly address important research questions have been proposed, applied and reviewed (Whitson \& Horne 2006, Preuss 2007, Getz 2008, Getz \& Page 2016).

It is argued here that the impact of mega sports events held in the mountain environment of Colorado such as the 1989, 1999 and 2015 World Alpine Ski Championships are hard to pin down in pecuniary terms as they are part of the continued, long-term efforts in retaining the racing events in town tied to previous engagements in the world cup races. During the two week high powered event, filled with over a dozen race competitions, some of the Vail Valley businesses may have even experienced financial losses as the general public avoided the region otherwise visited in high numbers during the ski season. The economic impact of the 1989 Championships was assessed at $\$ 55$ million by business consultants, with additional tax revenues of $\$ 1.45$ million for Eagle County (Rosall Remmen and Cares 1989). It can be argued that the investments made on and off the mountain in the preparation of the championships have even greater and lasting impact as they help to 'put' Vail and Beaver Creek, Colorado 'on the map'. \$ 2 billion in renovation were invested, for instance, during the years leading up to the 2015 events (personal communication John Dakin 2015). It has been estimated by the organizers that the 2015 Championships would cause "the flow of \$ 120 million to the region" (Colorado Public Radio 2015). Internally, hosting the mega events shown worldwide resulted in waves of modernization in town. All this reinforced local initiatives of staying on the cutting edge in communication and in providing state of the art hospitality services.

\section{COMPARING THE 1989, 1999 AND 2015 WORLD AlPINE SKI CHAMPIONSHIPS AND THEIR IMPACTS ON VAIL VALLEY}

The Organizing Committee's final reports 1989, 1999 and 2015 as well as interviews with John Dakin, a member of the Organizing Committee of all three championships in 1989, 1999 and 2015 and editor of the three final reports, as an official of the non-profit Vail Valley Foundation (with copy rights to the reports), formed the main basis for the present comparative analysis (Vail Valley Foundation 1990; Vail Valley Foundation 1999; Vail Valley Foundation 2015). While the 1989 and 1999 final reports were printed publications, of 128 and 142 pages respectively, the 2015 final report, with 32 full color slides, was issued on the internet.

Vail received the 1989 World Alpine Ski Championships after a first bid in 1983. One of the remarkable results and direct outcomes was that Vail became an identifiable place for the wider international skiing public with the 1989 Championships. While Aspen, host of the 1950 World Alpine Ski Championships, had been a known destination for many years, also for its summer season with the outstanding programs of the "Aspen Music Festival", Vail remained for long in the shadows. Worse, Vail Village was perceived by some of the European visitors as an inauthentic resort environment ('faux Bavarian') which badly reflected European architectural traditions and standards. As Vail Village eventually developed some patina and showed significant quality improvements in its public spaces in the 1990s/2000s/2010s, this initial negative perception faded away.

What Vail gained with the 1989 events was the image of a high quality skiing destination which was professionally managed. Incidentally, the 1989 Championships were blessed (or cursed) by enormous amounts of snowfall during the competitions which made an impression on perceptions abroad. While international visitation (in total visitation) to the Vail \& Beaver Creek ski areas before the Championships in 1989 was in the low range of $3 \%$ to $4 \%$, it rose afterwards to $13 \%-14 \%$. The 1999 Championships saw a similar spike in visitation after the events (personal communication John Dakin 2015).

1999 was in many ways a repeat of the 1989 events. Though, the 1999 Championships had improved race courses, in particular in Beaver Creek, as the highly praised 'Birds of Prey' downhill course for the men's competition was completed. By 2013, the new 'Raptor' downhill speed course (parallel to the 'Birds of Prey') was first used for the ladies race competitions during the World Cup and then during the 2015 World Alpine Ski Championships. The 'Raptor' (as did the 'Birds of Prey') demanded high technical skills from the downhill racers. Jointly with the Cortina (Italy) downhill course in the ladies' events, the 'Raptor' has been widely considered as one of the most challenging courses for women (Vail Daily 2012; Ski Racing 2013; personal communication John Dakin 2015) and reflects an overall intensification of the women's race competitions.

During the three championships, the finish areas for the races saw considerable improvements each time. For the 2015 Championships a new finish arena, the Red Tail Stadium 800 vertical feet above 
Beaver Creek Village, was built to potentially hold ten thousand spectators who cheered on their athletes. The number of athletes grew from 291 (from 42 countries) in 1989 and 300 (from 55 countries) in 1999 to 500 (from 68 countries) in 2015. More volunteers assisting the Organizing Committee were needed each time. In 1989, 1,233 volunteers were recruited; it was a respectable number in view of the fact that Vail Valley had a population of only 12,000 residents then. The volunteer numbers increased to 1,462 who provided 80,000 hours in 1999 and to 2,200 who provided 175,000 hours during the 2015 Championship events.

For the 1989 as well as the 1999 championships most of the races were organized on Vail Mountain and fewer in Beaver Creek. By contrast, in 2015 all the Downhill/Super-G/Giant Slalom/Slalom/Combined Races for both the men's and ladies' events were held in Beaver Creek leaving only one (new) team race for Vail. The Town of Vail was chosen to host the award ceremonies, where the medals were handed to the athletes in front of their supportive fans, as well as to provide the stage for a multitude of music and cultural events. During the 2015 events overnight stays at accommodations in Vail Valley reached a 95\% occupancy during the two weekends and surpassed or reached the overnight numbers on week days from the same time period in the previous year 2014; in total more than 29,000 room nights were generated. During the 1989 and 1999 championships, the occupancy rate was lower, at $70 \%$ to $80 \%$ (personal communication John Dakin 2015).

The press coverage during the events fundamentally changed. Transmission of news during the 1989 and 1989 events was by telephone and fax, and the photographs shot from the races and medal ceremonies had to be developed over night in neighboring Summit County before they could be released. There was no digital photography, no social media. 1999, though, had a web site. In 2015, an elaborate interactive web site was developed by the local organizing media team. The events had an impressive digital/social media/PR presence, in form of 40 million impressions and over 38,000 downloaded apps. During the events \#vail2015 trended as one of the Top Ten Topics on twitter. The directly communicated race events were seen by over 800 million viewers worldwide, with 70 hours of live international coverage and 35 hours of domestic coverage by NBC. It was a media feast made available for the large crowds of skiing fans in the Alpine countries as well as for people in the U.S. who had never before seen a ski racing event.

In summary, the first 1989 and the improved 1999 Championships were tightly centered on the race competitions, with focus on the main events and leading athletes in the sports scene. The organized events were largely directed to the special attention of the skiing world. The 2015 World Alpine Ski Championships marked a significant step away or up from this tradition; the press coverage on TV and in the social media was more broadly oriented, towards consumption by a wider audience. With the 2015 events, the Organizing Committee and the Vail organizers tried to reach out to the general public worldwide and in the U.S. - making, for instance, the case of a continued appeal of the skiing sport, in particular, to America's youth. The 2015 Championships were the "first complete event"; the celebration of the alpine skiing sport at Vail \& Beaver Creek in February 2015 presented itself as a "Mini-Olympic" (personal communication John Dakin 2015).

While population growth and change in Vail Valley/Eagle County from 1989 to 2015 cannot be attributed to the Championships in a narrow sense and/or continued in-migration to the County cannot be explained with an increased popularity of the skiing sport and the availability of more recreational opportunities in general, it provides a first answer to one of the main draws for living (and working) in Vail Valley. Population in Eagle County more than doubled over a twenty years period, from 22,000 in 1990 to 52,000 in 2010. The Towns of Vail and Avon experienced considerable growth in residents as well, from about 3,000 and 2,000 in 1990 to 5,300 and 6,400 in 2010. While Vail remained a core resort area and a main point of attraction for and in Vail Valley, Avon's community structure changed significantly, from the "no-longer-sleepy hamlet" and service center for Beaver Creek to a town with a distinct identity. The changes were attributed the 1999 Championships: "Everything has changed in Avon since 1999. They have stepped up their game in a big way ... Avon was starting from scratch, transforming itself from a worker-bee bedroom community into a bona fide destination" (Blevins 2015). Even more startling was the development of Edwards as an unincorporated community in Eagle County, some five miles $(8 \mathrm{~km})$ West of Beaver Creek. The small 'down valley' censusdesignated place (CDP) of Edwards grew rapidly to a community of about 8,200 residents in 2000 and of about 10,300 in 2010 . 
What has also changed over the past twenty-five years $(1989-2015)$ is the length of the urbanized corridor of Vail Valley, now stretching westwards another 20 miles $(35 \mathrm{~km})$ to the Town of Eagle and Gypsum. People once living in Vail have moved "down valley", e.g. to Edwards in unincorporated Eagle County where a good portion of the Vail Valley community life has played out (Williams 2003; Hartmann 2006, 2011).

Over the past few decades, Vail Valley has become a four season resort environment and an all season tourist destination. Cultural events in the summer, such as the nationally recognized Bravo! Vail Music Festival, and in the shoulder season - frequently accompanied by professional seminars/conferences - attracted a new crowed of (non-skiing) 'culture vultures' (Hartmann 2011). In addition, golfing and mountain biking became favorite sports available in many Vail Valley sections and locations. In recent years, agritourism in the form of food and wine tasting events, have further enriched the seasonal breath of offerings for Vail Valley visitors.

The Town of Vail incorporated in 1966 has seen in its fifty years' history a multitude of social, economic and population changes. Over the years some fifteen to twenty different town sections, with widely known place names and neighborhoods have evolved. The dynamic situation was largely steered by the Town Council's zoning decisions, expansion plans and frameworks. What has remained over the five decades are four clearly identifiable entities: Vail Village, Lionshead, East Vail and West Vail, with the latter two having their own highway exits in addition to the Vail Town Center Exit. Whereas Vail Village and Lionshead have been marked by high population densities, at first by permanent residency then by second home owners, East Vail developed as a low density residential section closest to Denver and the Front Range and West Vail as a mixed use area having the main retail businesses in town.

\section{THE ENVIRONMENTAL MOVEMENT's OPPOSITION TO FURTHER RESORT DEVELOPMENT on PUblic Lands: VAIL Ski AREA's EXPansions Under SCRUTINY}

The Wilderness Act of 1964 was approved by Congress with an overwhelming majority. It was the basis for establishing a large number of wilderness areas in Colorado including the Eagles Nest Wilderness Area (in 1976) and the Holy Cross Wilderness Area (in 1980). Both entities carved out of primitive areas, road-less areas and other national forest lands were formally declared a 'wilderness' which set the framework and limits to further development of the adjacent urbanizing Vail Valley corridor. It was these protected parts of the 'back country' and the White River National Forest lands that formed a core concern for the environmentally minded public.

In contrast to the ski areas with set rules within their boundaries and the established recreation centers, e.g. for cross-country skiing, the back country was open to anybody year-round. Little infrastructure or amenities were needed for a multitude of recreational activities which have become more and more popular over the years, from hiking and climbing, non-consumptive wildlife watching such as birding and nature photography trips in the summer and fall to snow shoeing and ski touring in the winter and early spring. For some, the set aside wilderness areas attained the status of a sacred land; for the large majority living in the Valley, it has been re-assuring that unspoiled nature was (still) within sight and easy reach.

This new appreciation of the natural qualities of the Colorado High Country - once perceived as a hostile territory but now revered by an increasing number of Colorado citizens - is an important backdrop to the two major conflicts involving the environmental movement and the ski industry as well as the National Forest Service in the late 1960s/early 1970s and in the mid/late 1990s.

The choice of Denver for the 1976 Winter Olympics made by the Olympic Committee in 1969 came as a surprise decision. Neither the local organizing committee, the initially chosen communities nor the National Forest Service were properly prepared. While the organizations and the leading individuals involved stumbled into the process, a formidable protest movement evolved. It was a period of rapid economic growth for the state favoring new business ventures including in recreation and tourism. Environmental groups like the Colorado Environmental Coalition started to criticize the unbridled growth of the ski industry including Vail Associates' expanded operations on Vail Mountain (resulting in sprawling resort development on the valley floor) as well as their planned launch of a new ski resort (Beaver Creek) with preliminary OK from the White River National Forest Service. As the debate continued, environmentalists laid out the dire financial and environmental 
consequences the Winter Olympics would have for the state and the Colorado High Country. In a special election in November 1972 the Colorado voter rejected subsidizing and hosting the Olympics, a first among chosen host cities. Subsequently in 1974, an alternative group of political leaders was swept in including newly elected governor Richard Lamm. While his opposition to Beaver Creek could no longer prevent the new resort, it considerably slowed the development process and raised the standards for implementing the plans. Times would change, with Denver making another run for hosting the Winter Olympics in 1988. The state was stuck in a severe stagnation/recession period in the mid/late 1980s after the crush of the extractive industries. Even Richard Lamm now supported the application, but Nagano (Japan) was chosen, with Denver coming in as a distant third (Childers 2012).

One of the major criticisms directed to the process of ski area development was that the National Forest Service was perceived as being too close (or 'cozy') with the ski companies including Vail Associates/Vail Resorts in the mid/late 1990s. It was the Category III expansion on Vail Mountain that outraged environmental groups. The last addition, a large expansion into China Bowl (plus Tea Cup and Siberia Bowls), was completed for the 1988/89 ski season to make the Vail Ski Area the largest ski area in North America (at that point in time). How much more skiable terrain was still needed for Vail, why would the National Forest Service allow them to disturb existing wildlife corridors and habitats in the backcountry, were some of the questions raised by the environmental community. The legal answer was that the Category III expansion had always been part of the Vail vision re-stated in the 1986 master plan. The conflict culminated in open discontent over and noncompliance with the procedures, and, at last, in the arson attack mentioned above.

What happened to the Category III expansion, what happened to the lynx? The Category III tracts of land were fully developed in 1999 and opened as "Blue Sky Basin" on January 6, 2000. In December 2000, another 125 acres were added to the 520 acres of varied skiable terrain. Though not as large as the China Bowl expansion, it has been a great asset to the Vail Ski Area as it opened the back bowl areas to the intermediate skiers. Another quality of the Blue Sky Basin was its North facing slopes enabling excellent skiing conditions even late in the season. From 1999 to 2006, 218 Canadian Lynx were re-introduced into the large Weminuche Wilderness Area in Southwest Colorado. It was a program partially subsidized by Vail Resorts. After fifteen years, the Lynx reintroduction program has been widely considered a success with a sufficient number of animals surviving and reproducing litter (at least 141 born in Colorado) (Devineau et al. 2010; Denver Post 2010). There were even a few lynx sightings in the Vail area. The lynx, now a less controversial figure, has become the mascot ("Milo", the Lynx) of the University of Colorado Denver since 2013.

\section{A Sustainable Future for Vail Valley}

Vail Resorts has become a leader in the implementation of environmental policies at ski resorts. What were the reasons or the context of a remarkable turn-around in attitude, from prevailing "ambitions of expansion" in the 1990s (personal communication Allen Best 2016) to embracing the fundamental principles of sustainability?

The first person to my knowledge who proposed the need for and the coming future of a 'green resort' was Terry Minger (1992), City Manager of The Town of Vail in the 1970s and later executive manager of several ski resorts including Robert Redford's Sundance in Utah. Initial support for the green resort idea came out of the Roaring Fork Valley pushed by the Snowmass Rocky Mountain Institute and Aspen Ski Company (SkiCo). It was SkiCo under the leadership of Pat O'Donnell which launched first initiatives in the unchartered field 1996 - 1999. A position for a Director of Environmental Affairs (eventually elevated to Vice President of Sustainability) - a first in the ski industry - was created and a newly established Environmental Foundation provided an institutional base with considerable financial resources for employees committed to local environmental causes. Aspen's environmental stewardship initiatives caught on. The National Ski Areas Association based in Lakewood, Colorado, developed a Sustainable Slopes program in 2004 (Hartmann 2011).

Vail Resorts was a latecomer to this field. However, eventually in 2006, the corporate offices (now in a LEED certified building in Broomfield on the Front Range) developed their own ideas and proposals in the environmental field such as "Use Less, Do More" (an energy conservation program), an effective recycling program (re-using $70 \%$ plus of the mountain's cardboard, aluminum, glass etc.) and programs in water conservation. The position of Director of Environmental Affairs at Rock 
Resorts International, Vail Resorts' flagship hotel brand, was established and a larger number of ambitious programs were proposed. It was Robert Katz, CEO of Vail Resorts since February 2006, who pushed for a sustainability agenda within the company: “...our environmental efforts are part of our responsibility to protect the very product we sell... Our company is dedicated to ensuring that RockResorts is on the path to being a leader in the travel industry in all major areas of sustainability" (Green Lodging News 2007). Vail Resorts was about to implement "pioneering (programs in) sustainability" for its resorts (HVS Eco Services 2010).

"Vail" (the "V" mountain signature design initiated by Dick Hauserman in 1961/62), has become one of the most highly recognized company logos in the ski industry. In the last decade, Vail Resorts created a new brand: "Epic", as in Epic (ski) pass for eight ski areas and Epic Discovery, the summer recreational programs on Vail Mountain (since 2016). Vail Resorts' environmental programs have been integrated in the EpicPromise Foundation: OUR COMMUNITY OUR MOUNTAINS OUR FUTURE. They comprise water saving programs (with the stewardship of their own and other nearby water resources including the return of $80 \%$ of the water used in snowmaking), in recycling \& reuse (including composting programs), energy reduction programs (allowing to produce more snow with less energy by using new compressors) and programs for the protection of forests, habitats \& wildlife (EpicPromise 2014). The new environmental agenda - now actively including Vail Resorts' employees in the eight ski resorts they manage - was widely communicated, internally within the company and through the local communities involved. In 2016, Vail Resorts matched up with the nationally and internationally recognized Nature Conservancy non-profit organization (The Nature Conservancy 2017, p. 7).

Several communities in Vail Valley have also made major efforts in the environmental field. Over the past two decades, The Town of Vail, for instance, has developed a convenient, reliable and free transportation system, running hybrid electrical buses for its residents, commuting workers and visitors. On a more general note, the Town introduced an environmental sustainability strategic plan, "Code Green - Building a Sustainable Future" (Town of Vail 2009), which was implemented for the 2015 Alpine World Ski Championships (Walking Mountain 2015). Most recently, the Town of Vail has taken the ambitious step of becoming the continent's first sustainable tourist destination certified through the Global Sustainable Tourism Council (Blevins 2017b).

Vail Resorts' latest initiatives comprise the "Epic Promise for a Zero Footprint", with the goal of eliminating the environmental impact of its operations by 2030 including delivering zero waste to landfills and to offset its overall impact to forests and habitat. The resort company promised to use only renewable energy by 2030. Vail Resorts also plans to join the RE100, a group of global companies committed to using 100 percent renewable energy (Blevins 2017a).

\section{SuStainAbiLITY OF SKI RESORTS FOR WHOM?}

At last, the goal of a sustainable future for Vail Valley seems to be long-term within reach. However, the question arises: Sustainability for whom? Living in the high quality, glamorous core resort areas of Vail and Beaver Creek has become enormously expensive, with real estate prices for homes averaging close to one million dollar; thus, the move to the down valley areas continues. Further, regular skiing/boarding days or weekends at the Vail and Beaver Creek ski areas have largely fallen out of reach for many winter sport fans in Colorado. While a ski lift ticket on December 15, 1962 was only $\$ 5$, day passes have surpassed $\$ 150$ during the last few ski seasons. Surely, there are tremendous differences in the quality of skiing now and then. The present-day Vail skier has 5,289 skiable acres through a fast and convenient uphill transportation system available and the boarder can enjoy three terrain parks - compared to a much smaller, less varied ski mountain, with hardly groomed runs 'in the olden days'. As to the visitors of Vail who came and went and those living there for work, the gaps in income appear to have widened over the years. This is most evident in the contrasting housing conditions, of the (mostly) Hispanic seasonal workers living in the down valley trailer parks and of the second home owners in their gated subdivisions some of whom hardly spend a few weeks during the year there. Another widely shared observation, at least in the Colorado context, is that Vail Resorts tends to prefer to cater (not exclusively but increasingly) to the wealthy. While employee housing opportunities have increased, equity issues persist and continue to mark today's Vail Valley environment. 


\section{Conclusions}

It all started with skiing, with a small, confined Vail Ski Area/Vail Village in the beginnings, which gave name to the place and the valley. As the resort grew up, matured, expanded and excelled, it received three times the honor of hosting a mega event in alpine skiing: the World Alpine Ski Championships. The high powered competitions brought the best athletes in the skiing world into town and to the Valley. Each time, the hosting organization and the residents, were faced with updating their skills, amenities and infrastructure to stage the events in state-of-the-art fashion. The championships and skiing, recreation and tourism in a wider sense have changed Vail Valley which has doubled in area size/population volume since 1989. The last chapter is not yet written, as the 2015 events may have been the pre-curser for future events. Vail Resorts' business operations continue to gain momentum nationally and world-wide. The most recent acquisition of Whistler Blackcomb (in July 2016), one of the highest ranked, if not the overall best ski area in North America (by skiable acreage and vertical drop), is proof of the company's drive to grow further and solidify its competitive market position. While the corporation guided the transformation of the Valley in past years, it may have its eyes set on the global market.

Vail Valley serves as an example of the globalization of the ski resort industry and of its continued impact on mountain environments observable not only in the Colorado High Country but in high mountain ranges worldwide (see, for instance, Zimmermann 2016 for the Alpine countries and Gill and Williams 2011, Gill 2012 for British Columbia, Canada). The growing and maturing resort areas of Vail and Beaver Creek have resulted - as noted for many other winter sports destinations - in urban sprawl and an ever expanding 'down valley' where equity issues have come sharply to the forefront of community agendas. While the goal of sustainability for prime resort locations has gained wide acceptability in the corporate world, a sobering realization and new awareness has entered the debate over the implementation of sustained growth policies on and off the mountain. It is the decreasing affordability of high quality resort development and the issue of equal access to the publicly administered surrounding environments, now increasingly pleasure grounds for the wealthy and privileged with considerable financial assets in the resort towns, that have raised red flags in the public sector.

\section{REFERENCES}

[1] Best, A. (1998). Vail and the road to a recreational empire. High Country News, December 7, 1998. Paonia, Colorado: High Country News, December 7, 1988, Vol. 30 (23), pp. 1, $10-15$.

[2] Blevins, J. (2015). "Everything has changed in Avon since 1999. They have stepped up their game in a big way", Denver Post, February 1, 2015, K1/10.

[3] Blevins, J. (2017a). "World's largest operator vows to be clean by 2030", Denver Post, July 26, 2017, pp. 10/12.

[4] Blevins, J (2017b). “Ambitious Vail welcomes "sustainable tourism”", Denver Post, July 29, 2017, pp. 13/15.

[5] Brown, R. and Burns, S. (2012). Vail: The Rise of America's Iconic Ski Resort (DVD). Vail, Colorado: Vail Resorts.

[6] Capital Projects Branch Province of British Columbia (2002). The Economic Impact of the Winter Olympic \& Paralympic Games - Initial Estimates. Victoria, B.C.: Province of British Columbia.

[7] Center for Public Policy \& Administration The University of Utah (2006). Economic Impact of the 2002 Olympic Winter Games, Policy Brief: 07-25-2006. Salt Lake City, Utah: The University of Utah.

[8] Childers, M. (2012). Colorado Powder Keg: Ski Resorts and The Environmental Movement. Lawrence, Kansas: University of Kansas Press.

[9] Clifford, H. (2002). Downhill slide - why the corporate ski industry is bad for skiing, ski towns and the environment. San Francisco: Sierra Club Books.

[10] Colorado Public Radio (2015). "World's Best Alpine Skiers Ready to Compete in The Vail Valley", http://www.cpr.org/news/story/worlds-best-alpine-skiers-ready-compete-Vail-Valley 
[11] Colorado Ski \& Snowboard Museum (2012). "Vail Dream Realized". Vail, Colorado: Colorado Ski \& Snowboard Museum, www.skimuseum.net/exhibits

[12] Colorado Ski \& Snowboard Museum (2015). Exhibit “1989, 1999 and 2015 World Alpine Ski Championships". Vail, Colorado: 2015.

[13] Denver Post (2010). "Lynx reintroduction ruled a success in Colorado", September 17, 2010, http://www.denverpost.com/2010/09/17/lynx-reintroduction-ruled-a-success-in-Colorado;

[14] Devineau, O., Shenk, T., White, G., Doherty, P., Lukacs, P. \& Kahn, R. (2010). "Evaluating the Canada lynx programme in Colorado: patterns in mortality", Journal of Applied Ecology, Vo. 47 (3), pp. $524-531$.

[15] Dorward, S. (1990). Design for Mountain Communities. New York: Van Nostrand Reinhold.

[16] Dorward, S. (2006).The Evolution of Village Form and Its Relevance as a Model for Resort Design and Development. In Clark, Gill and Hartmann (Eds.) Mountain Resort Planning and Development in an Era of Globalization. New York: Cognizant Communication Corporation, pp. $253-277$.

[17] EpicPromise (2014). The EpicPromise Foundation http://www.epicpromise.com/;

[18] Fay, A. (1984). Ski Tracks in the Rockies. Denver, Colorado: Cordillera Press.

[19] Getz, D. (1989). Special events: Defining the product. Tourism Management, 10 (2), pp. 135 137.

[20] Getz, D. (2008). Event tourism: Definition, evolution, and research. Tourism Management, 29 (3), pp. $403-428$.

[21] Getz, D. \& Page, Stephen (2016). Progress and prospects for event tourism research. Tourism Management, Vol. 52, February 2016, pp. $593-631$.

[22] Gill, A.M. (2012). Shifting the discourse from growth to sustainability: New approaches in governance in resort destinations. In Andreas Kagermeier \& Jarkko Saarinen (Eds.) Transforming and Managing Destinations: Tourism and Leisure in a Time of Global Change and Risks. Mannheim, Germany. Pp. 345 - 352.

[23] Gill, A.M. \& Williams, P.W. (2011). Rethinking resort growth: Understanding evolving governance strategies in Whistler, British Columbia. Journal of Sustainable Tourism, 19 (4-5): $629-648$.

[24] Green Lodging News (2007). "Vail Resorts Lays Out Ambitious Sustainability Plans for RockResorts", December 12, 2007, http://www.greenlodgingnews.com/Vail-Resorts-Lays-OutAmbitious-Sustainability-Plans-For-RockResorts;

[25] Hall, M. (1989). The definition and analysis of hallway tourist events. GeoJournal, 19 (3), pp. $263-268$.

[26] Hartmann, R. (2006). Downstream and Down-Valley: Essential Components and Directions of Growth and Change in the Sprawling Resort Landscapes of the Rocky Mountain West. In Clark, Gill and Hartmann (Eds.) Mountain Resort Planning and Development in an Era of Globalization. New York: Cognizant Communication Corporation, pp. 278 - 293.

[27] Hartmann, R. (2011). Ski Resort Development in Colorado: Current Trends and Issues. In Janschitz, S. and Lieb, G. (Eds.). Nachhaltigkeit - Regionalentswicklung - Tourismus, Grazer Schriften der Geographie und Raumforschung, Band 46. Graz: Institut fuer Geographie und Raumforschung Karl-Franzens-Universitaet Graz.

[28] Hartmann, R. (2015). Snow Sports and Ski Resorts. In Colorado: A Historical Atlas, Thomas Noel (Ed.), Norman, OK: University of Oklahoma Press, pp. $242-245$.

[29] Hauserman, Dick (2000). The Inventors of Vail. Edwards, Colorado: Golden Peak Publishing Company.

[30] HVS Eco Services (2010). "Vail Resorts: Pioneering Sustainability", http://www.hvs.com/ article/4350/vail-resorts-pioneering-sustainability/;

[31] Minger, T. (1992). "The Green Resort: Environmental Stewardship and the Resort Community", In Gill, A. \& Hartmann, R. (Eds.) Mountain Resort Development - Proceedings of the Vail Conference April $18^{\text {th }}-21^{\text {st }}$, 1991. Burnaby, B.C.: Centre for Tourism Policy and Research, Simon Fraser University, pp. 66 - 69. 
The World Alpine Ski Championships 1989, 1999 and 2015 in Vail, Colorado: Impacts, Issues and the Quest for Sustainable Resort Development

[32] Mueller, Martin (2015). After Sochi 2014: costs and impacts of Russia's Olympic Games. Eurasian Geography and Economics. http://dx.doi.org/10.1080/15387216.2015.1040432

[33] OGI-UBC Research Team The University of British Columbia (2013). Olympic Games Impact (OGI) Study for the 2010 Olympic and Paralympic Winter Games - Post-Games Report. Vancouver, B.C.: The University of British Columbia.

[34] Preuss, H. (2007). The conceptualization and measurement of mega sport event legacies. Journal of Sport \& Tourism, 12 (3-4), pp. $207-227$.

[35] Richie, B. (1984). Assessing the impacts of hallmark events: Conceptual and research issues. Journal of Travel Research, 23 (1), pp. 2 - 11.

[36] Richie, B. and Aitken, C. E. (1984). Assessing the impacts of the 1988 Olympic Winter Games: the research program and initial results. Journal of Travel Research, 22 (winter), $17-25$.

[37] Richie, B., Shipway, R. and Cleeve, B. (2010). Resident Perceptions of Mega-Sporting Events: A Non-Host City Perspective of the 2012 London Olympic Games. Journal of Sport \& Tourism, http://dx.doi.org/10.1080/14775080902965108

[38] Rosall Remmen and Cares (1989). The World Alpine Ski Championships Post-Events Evaluation. Boulder: November 1989.

[39] Seibert, P. (2000). Vail - Triumph of a Dream. Boulder, Colorado: Mountain Sports Press.

[40] Simonton, J. (1987). Vail - Story of a Colorado Mountain Valley. Vail, Colorado: Vail Chronicles.

[41] Ski Racing (2013). "Beav's new women's DH course named 'Raptor'”. https://www.skiracing. com/stories/beavs-new-womens-dh-course-named-'raptor'

[42] The Nature Conservancy (2017). Colorado Celebrating 50 Years of Conservation - Year in Review 2016. Boulder, Colorado: The Nature Conservancy 2017, page 7.

[43] Town of Vail (2009). Code Green - Building a Sustainable Future. Vail: Town of Vail 2009.

[44] Vail Daily (2012). "Women's downhill course almost complete", Vail Daily, September 14, 2012.

[45] Vail Valley Foundation (1990). Vail Beaver Creek 1989 World Alpine Ski Championships Final Report Compte Rendu Final Schlussbericht. Vail, Colorado: Vail Valley Foundation.

[46] Vail Valley Foundation (1999). 1999 World Alpine Ski Championships Vail Beaver Creek Colorado January 31 - February 14, 1999 Final Report Compte Rendu Final Schlussbericht. Vail, Colorado: Vail Valley Foundation.

[47] Vail Valley Foundation (2015). 2015 Vail Beaver Creek FIS Alpine World Ski Championships Final Report. Vail, Colorado: Vail Valley Foundation. http://www.vvf.org/athletics/2015-worldchampionships

[48] Walking Mountains (2015). Vail Displays Commitment to Environmental Sustainability During 2015 FIS Alpine World Ski Championships, published on line http://www.walkingmountains .org/2015/02/vail-displays-commitment-to-environmental-sustainability-during-2015-FIS-alpineworld-ski-championships/

[49] Whitson, D. \& Horne, J. (2006). Underestimated costs and overestimated benefits?: Comparing the outcomes of sports mega-events in Canada and Japan. The Sociological Review, 54 (s2), pp. $73-89$.

[50] Zimmermann, F. (2016). Nachhaltigkeit wofuer? (Sustainability for What?), Berlin: Springer Spektrum, $289 \mathrm{pp}$.

Citation: Rudi, Hartmann. "The World Alpine Ski Championships 1989, 1999 And 2015 in Vail, Colorado: Impacts, Issues and the Quest for Sustainable Resort Development." International Journal of Research in Tourism and Hospitality (IJRTH), vol 3, no. 3, 2017, pp. 43-53. doi:http://dx.doi.org/10.20431/24550043.0303005 .

Copyright: ( $) 2017$ Authors. This is an open-access article distributed under the terms of the Creative Commons Attribution License, which permits unrestricted use, distribution, and reproduction in any medium, provided the original author and source are credited. 